\title{
Assessing risk criteria and HIV prevalence in antenatal clinic clients from 2 urban tertiary hospitals in Pakistan
}

\author{
Naveeda Shabbir*, Qudsia Uzma, Shazra Abbass \\ From $16^{\text {th }}$ International Symposium on HIV and Emerging Infectious Diseases \\ Marseille, France. 24-26 March 2010
}

\section{Background}

Pakistan is in the concentrated phase of HIV epidemic for the last five years. The HIV prevalence among injecting drug users and hijra sex workers has been reported by second generation surveillance to be more than $5 \%$. Considering the risk of HIV transmission to the spouses and children of the high risk groups including migrant workers, the National AIDS Control Programme established six comprehensive prevention of parent to child transmission (PPTCT) sites linked with HIV treatment centres in tertiary hospitals. The objective of this study was to determine the HIV prevalence among antenatal clinic (ANC) attendees at two tertiary care hospitals and correlate risk assessment questionnaire with HIV diagnosis.

\section{Methods}

This cross-sectional study was conducted simultaneously at two PPTCT centers; Lady Wallingdon Hospital (LWH)-Lahore and Pakistan Institute of Medical Sciences (PIMS)-Islamabad from September 2008 to August 2009. A sample of 2589 at PIMS and 2983 at LWH were taken using convenience sampling technique. A risk assessment questionnaire was used to screen the at-risk group and then rapid HIV test was done. The positive cases were confirmed using ELISA.

\section{Results}

The total number of pregnant women screened through risk assessment questionnaire was 5572 (both sites). All of them consented for biological testing and were provided pre- and post-test counseling. Only three cases at

\footnotetext{
* Correspondence: dr_naveeda@yahoo.com

National AIDS Control Programme, Islamabad, Pakistan
}

PIMS were reactive on rapid HIV test, yet tested negative on ELISA. None of the cases from LWH was reactive on rapid HIV test.

\section{Discussion}

Based on the study findings, it is recommended that a revised strategy should be used for ANC screening in situations of low prevalence general population as in Pakistan. Moreover, the prevention strategies for general population should be strengthened. Referral linkages of PPTCT centers with NGOs working for people living with HIV/AIDS and most at risk population groups is critical for identifying HIV positive pregnant women and spouses of HIV positive men to access PPTCT services.

Published: 11 May 2010

\section{doi:10.1186/1742-4690-7-S1-P148}

Cite this article as: Shabbir et al:: Assessing risk criteria and HIV prevalence in antenatal clinic clients from 2 urban tertiary hospitals in Pakistan. Retrovirology 2010 7(Suppl 1):P148.

Submit your next manuscript to BioMed Central and take full advantage of:

- Convenient online submission

- Thorough peer review

- No space constraints or color figure charges

- Immediate publication on acceptance

- Inclusion in PubMed, CAS, Scopus and Google Scholar

- Research which is freely available for redistribution

Submit your manuscript at www.biomedcentral.com/submit
Biomed Central 